\title{
O Príncipe de Maquiavel - "Caixa de Perguntas"
}

\section{The Prince of Machiavelli - "A Questions Set"}

Ana Paiva ${ }^{1}$; António Cipriano².

1 E-mail:

cazadesantanna@gmail.com

Universidade Aberta

2 E-mail:

apedro.cipriano@gmail.com

Universidade Aberta
Resumo: Este artigo procura, à luz de uma leitura de O Príncipe de Maquiavel, esboçar uma reflexão crítica sobre os conceitos de poder político e Estado, e sua interligação com um projeto contemporâneo alternativo de ordenamento social e político. Inicialmente, os autores fazem uma biografia do conceito de Estado, tendo como pontos de partida a polis grega e a civitas romana até chegarem ao modelo proposto por Maquiavel, onde o poder do Estado deixa de estar vinculado a valores, convertendo-se o poder político no mais importante dos valores. Em seguida, reflete-se sobre a crise do Estado democrático e as implicações inerentes à desigualdade social. Por fim, discute-se uma proposta de um novo ordenamento social e político onde a ética social se apresenta como o valor de excelência. Num modelo alternativo de ordem política, caberá aos grupos sociais, enquanto unidades mínimas de soberania, potenciar um novo conceito de modelo político onde a fraternidade terá o mesmo peso dos outros dois pilares iluministas.

Palavras-chave: Desigualdade social; Estado democrático; Ética; Maquiavel, Poder político.

Abstract: Based on The Prince of Machiavelli, this article intends to make a critical reflection on the concepts of political power and State, and their interconnection with an alternative contemporary project of social and political order. First, the authors present a biography on the concept of State having as starting point the Greek polis and the Roman civitas until they reached the model proposed by Machiavelli, where the power of the State is no longer linked to values, becoming the political power the most important value. Secondly the crisis of the democratic state and the implications of social inequality are discussed. Finally, a proposal is made for a new social and political order where social ethic is presented as the value of excellence. In an alternative model of political order, social groups themselves, as minimum units of sovereignty, should develop a new concept of political model where fraternity will have the same weight as the other two Enlightenment pillars.

Keywords: Social inequality; Democratic State; Ethic; Machiavelli; political power. 


\section{Introdução}

No ano de 2013 registaram-se 500 anos sobre a escrita de $O$ Príncipe o que me levou a fazer uma releitura crítica desta obra central do pensamento Ocidental. Tendo sido $O$ Príncipe pioneiro na formação do espírito europeu moderno, agora que parece que nos encontramos no epílogo da modernidade assistindo a uma crise na ordem política e à cada vez maior afirmação na ordem social ${ }^{1}$, é oportuno não desperdiçar a ocasião de o reler com critérios não só políticos mas também sociológicos.

Se a época Moderna foi, por excelência, o tempo da afirmação do poder político através da criação e desenvolvimento do Estado Nacional, o mundo contemporâneo experiencia a angústia de ver esse modelo em agonia crítica de indefinição, sem que, no horizonte intelectual, filosófico ou científico surja outro que se afigure mais adequado à gestão do espaço e do tempo comuns. E enquanto o político vacila e parece, muitas vezes, pelo menos informalmente, soçobrar face ao civil, a sua enfraquecida função de regulação, de equilíbrio e de resistência à entropia social deixa espaço para novas formas de dominação não políticas - dizemos, económicas e financeiras ou comunicacionais, por exemplo.

Por esta razão, que é simultaneamente o declínio do Estado moderno e a ausência de alternativas políticas à sua dominação, reflectir acerca de $O$ Príncipe, 500 anos depois da sua escrita, deve impor-nos a tarefa de formular muitas perguntas, que nos obriguem a procurar respostas novas. Vamos portanto, iniciar uma "Caixa de Perguntas".

Assim, cumpre começar por perguntar se, "o político" está realmente em crise final, e evoluímos para outra/s forma/s de organização da dominação por via civil? Prosseguimos perguntando se, a ser assim, a civitas encontrará, na/s sua/s nova/s forma/s hegemónica/s (eventualmente alguma mão financeira invisível?) a capacidade de criar uma nova ordenação social que possa dosear coação com liberdade e segurança face à tensão anárquica que lhe é inerente, ordenação essa que possa aproximar-se da capacidade que, para isso, teve o Estado enquanto forma hegemónica de poder político, durante a Idade Moderna?

O Príncipe, entre as suas múltiplas facetas, revela a táctica e a estratégia adequadas para a conservação do poder nos novos principados, não hereditários e, portanto, não baseados 
no "sangue do seu senhor" (Maquiavel, 2011: 113), e por isso, contém o germe da ideia política de todos os novos Estados ou domínios políticos, e particularmente de todas as repúblicas modernas construídas contra as monarquias antigas e hereditárias e que, segundo Maquiavel, se adquirem "ou com as armas de outrem ou com as próprias, ou por fortuna ou por virtude.” (Maquiavel, 2011: 113). Será então, hoje, a conservação do poder de Estados particulares que está em crise? Ou o próprio conceito de Estado como forma de dominação legítima?

Esta crise evidencia o fim do político em sentido clássico? Ou estamos apenas a viver uma crise de crescimento/evolução resultante de algumas modificações e adaptações no carácter do político, tal como no tempo de $O$ Príncipe, se começou a desenhar o novo carácter (estatal) das dominações legítimas, que se consagraram posteriormente em diversas versões, desde o Absolutismo Real de Luís XIV, até, primeiro, os impérios Austro-Húngaro, Germânico e Russo, e depois, finalmente, em formas mais degeneradas, o nazismo, fascismo e bolchevismo?

Esta primeira questão serve, pois, para procurar a resposta à dúvida entre as hipóteses de, o civil estar ontologicamente inibido de, por si só, ordenar a liberdade, a justiça e a convivência pacífica e devermos procurar novas formas de ordenar a coisa pública, ou de, em alternativa, devermos declarar a morte radical do político entregando a civitas a si própria, coabitando assim com o leviathan, numa altura em que os sistemas de comunicação permitem, melhor que jamais, a auto-organização?

No actual estado das relações das sociedades políticas com as sociedades civis europeias, caracterizado pelos altos níveis de abstenção eleitoral e afastamento entre representantes e representados, parece que a procura de uma nova resposta à questão hobesiana da ordem, pode decidir se, ao comemorarmos o meio milénio da escrita de $O$ Príncipe, é mais urgente reescreve-lo adaptado à contemporaneidade, procurando encontrar novas guias para a manutenção do poder político e da ordem pública, ou se, devemos simplesmente arquivá-lo na prateleira dos tratados clássicos ultrapassados e elaborar outro tratado de dominação, eventualmente com o título, O financeiro, com o subtítulo, como ganhar e manter o poder em sociedades apolíticas.

Acerca da inumerável série de ideias e assuntos que a leitura de $O$ Príncipe já motivou e das particularidades específicas da obra, dos ensinamentos praxiológicos e das regras de 
obtenção dos fins políticos ensinadas por Maquiavel tem a ciência política exposto, desenvolvido e argumentado, com tal proficuidade, que acaso nos poderia ocorrer pensar que nada mais haveria, de novo, para dizer. Ainda assim, a densidade do político e do social, a opacidade do futuro e a ilusão da clareza do presente e do passado, mostram-nos que não há assuntos esgotados e esclarecidos. Vamos portanto, enveredar por uma reflexão que partindo apenas de dois ou três aspectos do pensamento do autor, permita um exercício que, à falta de melhor termo interdisciplinar, se situe no campo da sociologia política, mais que em qualquer outro. O presente artigo vai, por isso, esboçar uma reflexão contemporânea retomando o tema geral da obra, ou seja, o poder político, e em geral os aspectos da dominação.

\section{O poder}

Entendido o poder como "a oportunidade de fazer triunfar no seio de uma relação social a sua própria vontade, mesmo contra resistências" (Weber, 1999: 33), e sendo a dominação um dado antropológico que radica na própria ontologia humana e se actualiza em todas as acções sociais, então em cada papel desempenhado na sociedade, cada homem comanda ou obedece a outro ou outros homens. De facto, cada homem nasce em situação de incompletude, estando a sua sobrevivência sob o poder de outrem, normalmente os pais, que por sua vez o inserem na sociedade submetendo-o e educandoo para a obediência a diversas instituições com as quais vai interagir: a escola, nas pessoas dos empregados, professores, directores, inspectores, directores gerais de ensino, ministros; eventualmente uma igreja, um grupo desportivo, mais tarde a autoridade patronal, entre outras. O poder é sempre uma forma de relação social que se actualiza através de algum tipo de dominação. Ora, a dominação consiste, segundo Weber (ibidem), na "oportunidade de encontrar pessoas determináveis dispostas a obedecer a uma ordem de conteúdo determinado". A dominação é um fenómeno social ubíquo no tempo e no espaço.

O poder político é uma categoria particular de poder e da dominação, mas uma categoria singularmente distinta por ser, antes de tudo, uma acção exercida de forma contínua no espaço e no tempo, com capacidade para dominar sociedades inteiras através da acção organizada. O poder político visa, essencialmente, o exercício da dominação generalizada num determinado território, exercendo-se sobre todos os que aí vivem, de forma a criar uma ordem estável e a governar o interesse comum. A dominação política não é 
espontânea mas sim estruturada e estruturante e apoia-se na estratégia e na coerção física legítima, pois, o poder político exerce-se tendo como fundamento a lei e o reconhecimento do comando dos que o exercem por parte dos que a ele se submetem.

A afirmação do poder do Estado Nacional, embora de forma variada e passando do ténue ao brutal ao longo dos séculos, criou e estabeleceu por todo o lado, um poder abstracto e supostamente supra-pessoal, monárquico ou republicano, que conseguiu, de formas várias e mais ou menos problemáticas, criar um equilíbrio instável mas efectivo da natureza dominadora do homem. O conceito moderno de cidadania, liderado, ou pelo modelo republicano francês, ou pelo modelo aristocrático/democrático anglo-saxónico, impôs-se com base no domínio da lei e da ideia de bem comum, supostamente asseguradas por um poder político com recurso ao monopólio da violência física, da fiscalidade e da condução/controlo das formas de actualização da soberania através de modelos de representação mais ou menos democratizados - Estado.

Mas depois de conhecermos a história do Estado até ao século XXI devemos na nossa reflexão procurar ser tão prudentes como recomendou Maquiavel, o que pode significar, hoje, ao contrário dele, não tratar o poder político fenomenologicamente independente da ética e da justiça natural.

Devemos portanto formular uma outra pergunta inicial em paralelo com as anteriores, ou seja, se o político terá ainda a possibilidade de, seja de que forma for, criar uma nova ordem face à tensão anárquica inerente à civitas, que possa dosear a coação com a liberdade e a justiça no mundo contemporâneo, se ele se mantiver como domínio positivista independente da moral e do direito natural?

\section{Da Polis à Civitas política}

A democracia grega gerou a maior parte dos termos que estruturam o pensamento político subsequente e que chegaram aos nossos dias. Foi em função das categorias de polis e civitas que até hoje se pensou o poder e a dominação no espaço social. Sendo a Polis grega o domínio do bem comum e o espaço da criação da cidadania, ele foi tomado pelo pensamento das luzes e por todas as tentativas anti Antigo Regime, posteriores à Revolução Francesa, tais como o socialismo utópico, moderado e revolucionário, assim como pela social-democracia, como o espaço por excelência da actualização da democracia (exercício virtuoso do poder do povo pelo povo e para o povo). Todavia, a 
polis actual, tal como a grega, enferma de grave desigualdade social e isso entra em contradição o com o conceito contemporâneo de democracia ou pelo menos com as representações sociais da democracia. Na polis grega não participavam nem mulheres nem escravos nem estrangeiros, ou seja, a maior parte da população. A democracia era portanto restrita aos cidadãos (homens livres) e desenrolava-se à margem da vida económica (o espaço da produção material e dos serviços pertencia aos escravos) e da vida familiar. A civitas, ou seja, o que não era a polis, incluía a vida privada e o que hoje chamaríamos o "mercado" não havendo representação individual no poder mas apenas representantes das fratrias (famílias).

Em traços larguíssimos, o que a história política consumou até ao século XXI, foi o alargamento do espaço político democrático, ou seja da tomada de decisões acerca do bem comum, através da participação das mulheres no sufrágio, supressão do esclavagismo, e representação individual em vez de familiar, isto é, o alargamento da gestão da polis a todas os grupos sociais e a todos os indivíduos maiores de idade. Estendeu-se assim, quantitativamente o estatuto de cidadania ao alargar-se o grupo dos homens livres (cidadãos). Tal facto implicou, só pela aplicação da "lei da mudança qualitativa" da dialéctica, uma alteração substancial da prática democrática. A maior e mais determinante alteração que decorreu da mudança de escala do sistema político consistiu na alteração do modelo de representação que havia sido criado para a pequena escala, e que supunha a expressão directa da vontade dos cidadãos, ou seja dos homens com direitos políticos, direitos de decisão e governo dos demos, os quais eram uma pequena elite - democracia directa.

O homem contemporâneo, digamos pós-iluminista, acalentou a esperança de encontrar um sistema de representação operatório capaz de ombrear com a democracia directa ateniense tendo desenvolvido variadíssimos esforços e modelos concretos, para que fosse legítimo designar de democráticos os sistemas de cidadania inspirados na cidadania democrática antiga, mas agora aplicados também às massas e não somente às elites. A História mostrou que a mudança dialéctica da quantidade, convertida em qualidade, teve implicações mais profundas no exercício da dominação, do que os idealistas políticos da democracia iluminista e contemporânea provavelmente sonharam.

Desde logo, a "grande complicação" do sistema democrático deu-se quando, por acção da ampliação numérica dos cidadãos, a polis e a civitas se integraram e permearam (pelo sufrágio universal cada cidadão é um político), ou seja, os que produzem bens e serviços 
passaram a ser parte integrante dos que governam a polis, e os políticos, são homens com actividades económicas, aliás a própria política é uma actividade económica. Ou seja, as elites políticas não desapareceram mas, ao contrário das elites gregas antigas, não são constituídos por nobres com essa função exclusiva, mas por quaisquer membros eleitos dos demos (territórios) ou seja, povo e elites económicas, militares, intelectuais, proprietários, empresários, financeiros, entre outras.

A democracia clássica foi concebida para governar pequenos espaços (demos), organizados em famílias (grupos e não indivíduos) representadas por chefes (de família) através de uma aristocracia (genoi) sustentada por uma classe produtiva sem interesses económicos, os escravos. Aquilo a que chamamos hoje democracia, é, em geral, um sistema concebido para governar massas, em longos territórios, com indivíduos que são representados por profissionais da política os quais, na sua maioria desconhecem, e que lhes pedem (aliás persuadem, recorrendo a marketing e estratégias nem sempre honestas) que sejam seus representantes. Estes representantes sustentam-se a si próprios através da actividade política profissional e tem interesses económicos particulares (Weber, 2000). Os referidos poderes de representação são sufragados pelo voto universal e com a ausência da aristocracia "decapitada" com Luís XVI. A elite política é assim uma elite de raiz popular (do demos) que, através de partidos, governa, supostamente tendo em conta os interesses do seu grupo em nome do interesse comum, o que justifica que continue a chamar-se político ao seu poder, ou seja que governa a polis. No entanto, a prática mostra que esta elite política vive cada vez mais afastada dos demos de onde provém e se especializou na criação e manutenção de redes de contacto e influência, utilizando os recursos económicos do Estado para a sua manutenção no poder, nomeadamente através da administração dos bens comuns, gerindo empresas públicas ou participadas (Cruz, 2013).

Não é um detalhe aquilo de que estamos a falar. Efectivamente, o idealismo iluminista e revolucionário francês, que conduziu o estabelecimento da "democracia contemporânea" contra a teoria política aristocrática e as ideias de manutenção do poder absoluto, expressas em O príncipe de Maquiavel, foi actualizado através de uma consolidação estatal e imperial napoleónica que estabeleceu, por decreto e expedientes burocráticos, o conceito de citoyen, ou seja, o conceito de cidadania à francesa. Na cidadania à francesa todo o cidadão (estatuto ainda não universal na época) é chamado a participar na polis, pelo sufrágio, apesar de a sua vida, na esmagadora maioria dos casos, se desenrolar 
essencialmente no mundo dos interesses privados ou civis. A ausência da aristocracia permitiu então ao Estado uma centralização e uma dominação que abrangeram cada vez mais áreas da esfera privada. A isso mesmo se referiu Allexis de Tocqueville quando em Da democracia na América escreveu que “É apenas o governo que herda todas as prerrogativas arrancadas às famílias, às corporações ou aos homens, à força, por vezes opressiva, mas frequentemente conservadora, de um pequeno número de cidadãos sucedeu, portanto, a fraqueza de todos (Tocqueville, 2002: 46).

Assim se abriu o caminho para a polis ser governada pela civitas, sendo considerado essa a grande novidade democrática e o desiderato máximo da democracia contemporânea. Mas uma das consequências de tal opção foi que o futuro fosse um campo de combate entre interesses individuais legitimados através de sistemas de representação dita democrática - o poder do povo exercido pelo povo, através da luta política legítima partidocracia. No entanto, este "povo" não era um grupo familiar com escravos garantindo-lhes a sobrevivência com bem-estar, mas pessoas livres, em estado de necessidade, na sua maioria, defendendo-se a si próprias e, portanto guiando-se pelo individualismo e o oportunismo, tal como é próprio da sua ontologia. Ora, ser nobre e altruísta quando nada nos falta e alguém provê às nossas necessidades materiais com o seu trabalho (escravos) é significativamente diferente de ser altruísta e virtuoso quando temos de nos sustentar e preocupar com a nossa sobrevivência material e a dos nossos dependentes. Terá isto sido pensado pelos ideólogos da democracia moderna? Provavelmente não, o que é normal, porque da enorme complexidade do fenómeno social total, só conseguimos apreender uma parte e essa tem sempre a ver com a nossa experiência pessoal, a nossa localização histórica e social, a nossa ideologia, ou, nas palavras de Sedas Nunes (1977: 56-68), acerca das representações sociais, o "máximo de consciência possível" das classes sociais a que pertencemos e os nossos universos de pensamento.

Portanto, como consequência não prevista da voluntarista e altruísta ideia da democracia de massas, encontramo-nos hoje num sistema complexo, injusto e plutocrático a que ainda gostamos de chamar democracia mas no qual os demos se sentem cada vez menos representado pelas elites. Triunfaram então Maquiavel e Hobbes nos seus conceitos de poder absoluto? Também não, porque nem o Estado em si é hoje forte. O poder parece que entrou em deriva e nem é do povo nem do Príncipe, é do mercado financeiro que se tornou Império e Leviathã porque, como escreveu Becerra da Costa (2012: 23), " A 
democracia do povo, pelo povo e para o povo, degenerou numa partidocracia...”. A civitas domina então a polis através da sua aristocracia financeira.

Parece, portanto, que as experiências democráticas ocidentais viveram sempre condicionadas pelo facto de resultarem de uma adaptação de princípios contraditórios e paradoxais, ou seja, de querer governar a polis, através da civitas de um modo que não impediu que se "infectasse" o espaço nobre do bem comum pelos interesses dos bens particulares, esvaziando assim o sentido da polis e tomando-lhe o nome para exercer a dominação legítima. As repúblicas, por excelência ditas democráticas, têm tentado governar o ingovernável, apelando à virtude dos cidadãos e esquecendo-se de procurar fórmulas sistémicas para impedir as consequências naturais da lei ontológica da sobrevivência que se rege pelo egoísmo e não pelo altruísmo. O sistema é contraditório e por isso instável mantendo por resolver velhos dilemas tais como o da igualdade/liberdade ou o da convivência entre maiorias que impõem a sua vontade às minorias, ferindo a liberdade individual que defendem.

Hoje, parece que esta dinâmica contraditória entrou num certo caos a que chamamos crise do Estado ou da democracia, levando-nos a um limite inaceitável em que a civitas com grande pujança não só domina como espolia a polis, através dos recursos legais criados pela plutocracia partidária. Esse fenómeno parece ser conseguido graças à existência de um forte capital social de tipo bonding ${ }^{2}$, resultante das redes de relações sociopolíticas que se construíram em torno do governo da coisa pública (Cruz, 2013).

As elites políticas democráticas contemporâneas alimentam-se portanto das contradições de um sistema político complexo mal adaptado, resultante de uma mescla de ideais e valores virtuosos, com modelos clássicos greco-romanos desenvolvidos para uma sociedade completamente distinta da realidade contemporânea, e com ocorrências históricas particulares e ideologias revolucionarias que resultaram de um longo processo de evolução dos sistemas de dominação. Essas mesmas elites, que o vulgo julga inspiradas por Maquiavel, desdobram-se em estratégias para manter o poder, mas quanto mais as constroem, mais parece que só o leram parcialmente, pois mais se afastam do povo da civitas, parecendo esquecer que o mestre disse que “....alguém que, contra o povo se torna príncipe com o favor dos grandes deve, antes de qualquer outra coisa, procurar ganhar o povo, o que lhe será fácil desde que tome a sua protecção...a um príncipe é necessário ter 
o povo por amigo; de outra maneira, não tem remédio na adversidade" (Maquiavel, 2011: 157).

Para o autor de $O$ Príncipe, tantas vezes acusado de cinismo, o mundo social era ainda dividido entre polis e civitas, sendo o primeiro termo para o conjunto dos que exerciam a dominação (mesmo que amoral e oligárquica) e o segundo para os que se dedicavam aos negócios, como se percebe pelo que escreveu na sua carta a Francesco Vettori acerca de si próprio, "a fortuna fez com que não sabendo discutir nem sobre a arte das sedas e das lãs, nem sobre ganhos e perdas, eu tenha de falar do Estado. E é-me necessário ou falar de política ou fazer voto de silencio" (Maquiavel, 2011: 20).

A ideologia francesa iluminista concebeu o estado democrático, contra as ideias de Maquiavel e dos teóricos do poder absoluto, tendo como modelo a democracia ao estilo grego sem ter em conta o fenómeno social total, ignorando diferenças significativas entre aquela sociedade e as sociedades modernas. Obcecada pela ideia de erradicar a aristocracia, prestou grande atenção à igualdade e, embora tenha preconizado os valores da liberdade e da fraternidade, tendeu a relegar este último para segundo plano, pois a implementação da fraternidade é praticamente impossível por via revolucionária. Assim se criou uma tradição democrática ou baseada na igualdade ou baseada na liberdade, mas sempre ideologicamente revolucionária, isto é, criando uma ordem com base na destruição e não na evolução da ordem social anterior. A fraternidade ficou por atingir. Assim também se criou outra contradição no sistema, pois a implementação da igualdade forçada destrói a liberdade dos indivíduos e a implementação da liberdade, conduz à desigualdade (Tocqueville, idem) sendo que ambas conduzem naturalmente ao conflito, ou seja à anti-fraternidade. Por outro lado, com o tempo, a desigualdade social gritante tornou-se novamente um problema central nas sociedades ocidentais, desta vez através da desigualdade de classe e não da existência de ordens formais. Efectivamente, a existência de ordens é de origem medieval e foi mantida pelo Antigo Regime até à Revolução Francesa. Uma ordem ou estado é um estatuto social formal garantido pelo Estado. O povo representa à data da Revolução Francesa, o Terceiro Estado. Nessa altura a lei implementou a cidadania, baseada no conceito de igualdade formal perante a lei, revogando-se todos os antigos estatutos ou privilégios (leis privadas) e institucionalizando-se a lei universal que relaciona directa e exclusivamente o cidadão com o Estado. Esse é o princípio republicano da igualdade. Enquanto no Antigo Regime, a mobilidade social era muito fraca, e feita quase exclusivamente através do primeiro 
estado - o Clero, nas sociedades democráticas modernas o estatuto de cidadania permite uma mobilidade social muito grande, pois, tende a oferecer igualdade de oportunidades por via formal e a desigualdade social ocorre através da localização das pessoas no processo produtivo (Marx - classes sociais). Por outro lado, a tecnologia, a financeirização da economia e a forma de produzir riqueza, deixaram contingentes enormes de pessoas fora do processo produtivo ou em situação precária - desemprego estrutural. Isso foi uma das circunstâncias que mais contribuiu para a alteração das situações de classe, a tal ponto que hoje já se utilizam outros critérios para caracterizar a desigualdade, falando-se na enorme classe de Massa que engloba as antigas classes trabalhadoras com a decadente classe média (Gaggi e Narduzi, 2008).

De facto, o presente momento, a crise da democracia também se caracteriza por uma acentuada mobilidade descendente da classe média, nomeadamente porque é chamada a pagar os elevados défices públicos que os Estados criaram. As classes baixas encontramse, praticamente, impedidas de ascensão pois são amplamente atingidas pelo desemprego estrutural. Verifica-se que a classe que hoje mais permite a ascensão social é a "classe política", desempenhando ao nível da classe média um papel semelhante ao executado outrora pelo Primeiro Estado. O Estado é portanto um veículo de desigualdade social e de transformação/perversão da democracia. $O$ facto de ser por excelência um meio de mobilidade social transforma a luta política num campo de intriga e traição uma vez que são poucos os lugares que permitem a mobilidade e muitos os que os procuram. Nesta luta pelo poder, naturalmente, o homem/animal continua a mobilizar o seu cérebro antigo mais que os córtexes modernos onde se desenvolveram os valores sociais superiores.

O Estado contemporâneo encontra-se prisioneiro, quer deste mecanismo de ascensão social interna, quer das políticas que permitiram a afirmação do capital financeiro a nível global e financiaram o próprio endividamento do Estado. Por outro lado, a austeridade que caracteriza a actual política europeia reforça a contracção da classe média reduzindo o seu rendimento disponível e empurrando-a do ponto de vista cultural para o acesso às massificadas indústrias culturais (Warnier, 2000), em oposição à procura da cultura clássica e do conservadorismo que caracterizavam as antigas classes médias. Portanto, o Estado endividado reduziu o seu investimento em bem-estar social e em cultura, ferindo o Estado Providência, a mobilidade e a possibilidade de igualdade social (Schanapper, 2002) que era garantida pela sociedade política abstracta, composta de indivíduos civil e juridicamente livres (Schanapper, idem) e iguais, e atacou o rendimento das classes 
médias, que por sua vez reduziram os seus níveis de consumo e investimento e deixaram a economia em crise. O movimento de contracção do Estado não foi suficiente para resolver o seu problema financeiro e implicou, em simultâneo, uma aparente expansão do seu domínio e do seu papel de interventor na economia, o que tem tido como consequência paradoxal, a sua necessária expansão. De facto, destruído o tecido produtivo dos pequenos e médios proprietários e o poder de compra da classe mais consumidora de bens e serviços, a estagnação económica obrigou o Estado a investir na economia. Assim, o Estado foi o grande autor da mudança social (redução de salários e de transferências para as famílias, aumento de impostos, regulamentação e controlo de actividades civis etc. e investimento público). Ora, como é que um Estado falido pode reanimar a economia através do investimento? Com recurso aos grandes financiamentos privados com os quais estabeleceu acordos de cooperação, através das tão famosas em Portugal, Parcerias Público Privadas ${ }^{3}$.

Foi este o caminho seguido nas últimas décadas criando uma espiral de endividamento do Estado e estagnação da economia por contracção económica das famílias. Como isso foi feito de forma praticamente irreversível a médio prazo, deu origem a um equilíbrio comprometido entre o Estado e os grandes grupos financeiros, ou seja, os bancos (nacionais e estrangeiros - o que diminuiu ainda mais a soberania do Estado) que financiam o défice e as obras públicas. Assim, a polis foi confiscada pela civitas e a sociedade dos cidadãos (Schnapper, 1994) supostamente regida pela lei única, foi “contaminada" pela emergência de novos estados (ou ordens), isto é, novos estatutos privados, leis particulares que garantem privilégios e desigualdades ao sector financeiro e empresarial do Estado. Este foi, talvez o grande precedente estatal que veio a conduzir à crise das democracias, tais como foram concebidas e implementadas pela Revolução Francesa, e iniciou o fim de uma verdadeira comunidade igualitária de cidadãos, uma vez que sobre o estatuto de cidadania se estabeleceram novas ordens ou estados (estatutos diferentes e particulares que se consubstanciam em privilégios) todos eles laicos, que começam a configurar uma sociedade não democrática em que estamos a viver: ordem financeira, ordem política e terceiro estado ou ordem de massas.

As ordens emergentes sobre a lei geral da cidadania democrática podem identificar-se através do estudo das relações entre grupos financeiros e políticos profissionais que têm ou tiveram funções governativas e cargos partidários, como está evidente no recente estudo de Pedro Miguel Cruz - Um ecossistema político-empresarial Portugal 1975- 
$2013^{4}$. Tal estudo deve ser complementado pelos estudos de mobilidade social através dos cargos estatais e outros. A análise legislativa constitui um outro processo de avaliação da emergência de ordens no seio das sociedades democráticas. Veja-se o caso do sigilo dos privilégios (lei privada) atribuídos à ordem política pela lei n. ${ }^{\circ} 64 / 2013$, de 27 de Agosto, nomeadamente o disposto no artigo $1^{\circ}$ e na alínea b) do n. 3 do artigo $2^{\circ}$. Essa lei aprovada pela Assembleia da República, ou seja, pelos representantes da classe de massas, atribuiu à ordem política prerrogativas negadas aos restantes cidadãos, nomeadamente a possibilidade de omitir a declaração dos benefícios concedidos pela administração pública a particulares, nos quais se incluem pensões a ex-deputados, presidentes da República, ministros e primeiros-ministros, governadores de Macau, Ministros da República das Regiões autónomas e membros do Conselho de Estado, bem como juízes do Tribunal Constitucional. Estamos, portanto, face ao surgimento de ordens ou estados (a ordem define-se por critérios jurídicos e privilégios - leis privadas) no sistema de classes supostamente igualitário, próprio das comunidades de cidadãos das democracias modernas.

A afirmação dos estados ou ordens no seio das sociedades de classes parece, pois, ser um traço que vai reforçar-se no futuro, tal foi a evolução económica e social das últimas décadas e, por isso, devemos tê-la como uma das características da evolução da polis e da civitas. Na realidade, este estado de coisas tenderá a naturalizar-se, uma vez que parte da sociedade civil parece começar a sentir como justificados os privilégios e a existência de ordens dado que elas são, por agora, o garante do mínimo de uma certa coesão social. Isto mesmo se demonstra na aceitação da intervenção dos Estados na salvação de empresas privadas financeiras (bancos) em falência (mas não outras empresas, em geral), para, "evitar um mal maior", transferindo para o cidadão comum, a responsabilidade pelos maus resultados de gestão de empresas privadas. Este fenómeno parece funcionar como mecanismo de reforço da tendência de sobreposição de dois sistemas de estratificação social que caracteriza a crise da democracia e do Estado. Assim verificamos que hoje é o mundo financeiro que tende a decidir e ordenar os mercados (civitas contra a civitas) através do Estado (civitas politica oportunista) que consagra esse ordenamento pela via jurídica e garante a submissão das massas através do aumento da cobrança de impostos e da regulação laboral e administração do território. Em contrapartida, a ordem política recebe cargos, "títulos" e "honras", benesses e "luvas" da ordem financeira. Cabe ao Terceiro Estado ou cidadão comum (as massas) trabalhar e consumir a sua própria 
produção que é rapidamente variável porque corresponde às múltiplas decisões financeiras (estratégias de investimento bolsista, especulação, compra e venda de futuros, etc.).

Ora, como a mobilidade social ascendente se faz muito frequentemente através da ordem política, e esta está "refém" da ordem financeira, para manter o seu poder e posição social, a polis perde o seu carácter de bem comum e os políticos o seu carácter de administradores da coisa pública em nome dos cidadãos, para se tornarem nos agentes dos seus interesses e dos interesses financeiros dominantes, factos que se ligam e confundem - esvaziamento da política no seu sentido nobre, e sua substituição pela cupidez do interesse privado orientado egoisticamente (Varela, 2012) . Parece que na sociedade contemporânea, a política envelheceu e portanto perdeu a sua razão de ser.

Sabemos que toda a realidade está sujeita às leis da dialéctica e que a mesma lei que impediu a aplicação do modelo democrático grego às sociedades de massas contemporâneas, pode simplesmente transformar o carácter da polis, por acrescento de pequenas mudanças quantitativas até a mudança qualitativa radical, de forma que a polis deixe de o ser verdadeiramente para se tornar noutra qualquer coisa cujas características para já desconhecemos. Será isso a que estamos a assistir?

No presente momento, a política, ou governo da polis, parece ter-se transformado apenas na civitas contra a civitas nesta velha Europa em declínio acentuado. Poderemos então falar em vestígios de uma guerra civil de expressão não militar mas social e financeira, quando assistimos aos inúmeros episódios de protestos, greves e manifestações, por vezes com desordem e violência, por toda a Europa contemporânea, perante a incapacidade dos políticos de apaziguarem a sociedade e equilibrarem os múltiplos interesses que se defrontam na civitas? A civitas política a que nos conduziu o ideal democrático contraditório do iluminismo inclina-se portanto, para ser uma sociedade apolítica.

Deveremos clamar por novo Maquiavel que nos ensine a salvar o Estado, seja a que preço for, ainda que sem ética e justiça? Isso já foi tentado e a IIGM ainda não foi esquecida. Ou chegou a hora de construir tudo de novo e perceber que a nossa polis não pode ser a polis grega (até porque não aceitamos formalmente a sua desigualdade social) mas que a nobreza (não a aristocracia) é de facto a condição sine qua non da existência de uma verdadeira polis? Poderemos então dizer que o futuro da polis será ético ou nada será? 


\section{Da civitas política à polis civil, ética ou a nova polis}

Como temos vindo a tentar demonstrar, a polis foi tomada pela civitas e esvaziou o sentido do estado democrático de inspiração iluminista que julgou que só a civitas politizada poderia assegurar a democracia de massas através de um sistema de representação baseado no sufrágio universal. A história dos últimos dois séculos encarregou-se de mostrar que a civitas natural é hobesiana, no sentido de concorrência de interesses de todos contra todos, e esse carácter invadiu a polis através de mecanismos que aliaram a ordem política (polis) à ordem financeira (civitas), contra a ordem terceira ou ordem de massas (civitas), até ao eminente ponto de ruptura. O sistema de representação que mantém a ordem política afastada da ordem de massas está completamente desacreditado e é um verdadeiro obstáculo à democracia. Sendo a ordem financeira parte da civitas, temos hoje a civitas contra a civitas.

Será a democracia impossível? O conceito iluminista de democracia, sim parece impossível e esgotado. O próprio termo é "impróprio". A democracia era o governo do bem comum dos territórios (demos). Uma democracia injusta porque tinha base na desigualdade. $\mathrm{O}$ homem contemporâneo foi formado na ideologia da igualdade e parece encontrar na sua natureza material o eco desse seu desiderato, pelo que não suporta a ideia de desigualdade. Fukuyama (1992) considerou que a democracia liberal constituía "O Fim da História", por assegurar simultaneamente a liberdade através do mercado e a igualdade (isothymia) política que seriam ontologicamente necessárias à espécie humana. O autor via nas imperfeições das democracias liberais apenas questões de crescimento e maturidade dos casos particulares concretos, sendo que segundo ele, "o ideal da democracia não podia ser aperfeiçoado" (idem: 13). Parece que Fukuyama estava enganado pois a democracia não conseguiu nunca encontrar uma fórmula concreta de actualização da igualdade e da liberdade, uma vez que a sua implementação nunca permitiu superar a desigualdade natural e a repartição da riqueza criada pela economia liberal.

A base ideológica do Estado liberal parece ter sido, em grande parte, também a filosofia hegeliana que afirmava a necessidade de os homens desejarem ser concorrentes uns dos outros e ganharem o reconhecimento da sua superioridade na sociedade (megalothymia). O mercado, como espaço de afirmação de aptidões superiores para a conquista material permitiria suprir esse impulso natural para a concorrência que, segundo o autor, 
conduziria a uma diferenciação aperfeiçoadora do ser humano. De facto, a democracia liberal confirmou a desigualdade e também o limite da liberdade através do Estado que atingiu quase todas as áreas da vida humana, ordenando-as e tributando-as, desde o trabalho ao consumo de tabaco ou à doação de bens, entre outras.

As ciências neurológicas actuais disponibilizam-nos novos dados para repensarmos o conceito de bem comum, o papel e o formato de novos regimes políticos mais conformes à natureza humana e suas necessidades materiais. A nova filosofia política não pode dispensar a evidência científica multidisciplinar, embora tenha de se acautelar com o equívoco positivista da tentação científica.

Que regime político poderá suceder à democracia liberal para se superarem os eternos e cada vez mais actuais, problemas da igualdade e da desigualdade? Deveremos regressar ao direito natural com base nos conhecimentos neurológicos, e a uma reformulação de base naturalista das nossas instituições?

A ciência neurológica contemporânea (Paiva, 2007) tem mostrado que:

- A igualdade é um conceito não natural. Os indivíduos são desiguais porque o desenvolvimento da vida assenta na potencialidade e na liberdade determinística ontológica dos indivíduos.

- A vida humana é dirigida pela finalidade da sobrevida com bem-estar (não a mera sobrevida).

- A homeostase humana está directamente ligada à actualização da necessidade ontológica da ética porque a ética é materialmente necessária.

Estas premissas levam-nos a concluir que a actualização da desigualdade natural, ou exercício da identidade individual, é maximizada pela acção ética. Ora, a acção ética é aquela que permite a afirmação individual pela alteridade solidária, ou seja, pela compatibilização entre o "eu" e os "outros", ou o indivíduo e a sociedade. Daqui se conclui que a acção ética, sendo a que garante simultaneamente o bem-estar individual e social, deveria ser a característica dominante da acção política (acção de garantia de boa gestão do bem-estar comum). Do mesmo modo, toda a acção que não maximize o bemestar comum não serve a natureza humana e não conduz nem à homeostasia individual ou colectiva, não devendo, por isso, ser considerada acção política. 
Assim, afirmamos que a nova polis será ética ou não terá futuro e se prosseguirmos na via política actual continuaremos a assistir ao fim da política como gestão da coisa pública, impondo-se de futuro uma nova sociedade do tipo das medievais, onde as ordens de privilégio serão progressivamente mais institucionalizadas e a massa sem privilégios será a esmagadora maioria, face a uma elite de poder - impossibilidade de realização da natureza humana. Pior do que o conceito maquiavélico de um príncipe acima do seu povo e de um povo com o príncipe todo-poderoso, caminharemos para uma nova aristocracia política e financeira, fechada no seu Versalhes a escutar a turba faminta pedindo pão rolarão cabeças na guilhotina.

\section{Que procurar implementar num novo regime?}

A ética é o domínio do homem social, o homem em interacção recíproca e solidária com o seu grupo (singuli/coetum). Ora, os grupos mantêm-se coesos e solidários em proporção do capital social positivo que criam. A ética social será pois, o meio, por excelência da implementação da acção política e da criação de capital social que conduzirá à coesão grupal/societal. Assim sendo, a acção política dos grupos deveria ser o garante da sobrevida com bem-estar para todos os seus elementos. Falamos de grupos numa época em que as formas de solidariedade não têm necessariamente uma base territorial e podem mesmo ser de tipo virtual, pois a sociedade contemporânea é cada vez mais desterritorializada. Não cabe neste artigo desenvolver mais esta ideia, mas seria do máximo interesse fazê-lo posteriormente pois isso terá influência directa na política e gestão do Estado e definição das fronteiras políticas e sociais.

Regressemos às perguntas que enchem a nossa caixa, para reflectir no que poderia ser uma nova polis. Desde logo, a futura polis não deverá ser coetocrática, em vez de democrática, isto é, não deverá ter por base o poder de grupos sociais, independentemente do seu locus? Chamar-lhe-1́amos coetocracia? Esta designação teria a vantagem de identificar um começo e portanto afirmar uma diferença em relação à nossa esgotada democracia.

Em segundo lugar, não deverá a coetocracia consagrar a existência de novas ordens ou estados, uma vez que a desigualdade presente face à localização dos indivíduos no processo produtivo (nomeadamente os altos níveis de desemprego) não deve estimularnos a perpetuar uma sociedade de classes ${ }^{6}$ ? Simultaneamente, desta forma, a actualização 
da necessidade da liberdade e da diferenciação no ser humano não poderiam ser melhor atingidas?

Em terceiro lugar, não deveria a coetocracia institucionalizar a existência de apenas duas ordens não hierárquicas, baseadas em tipos de acção social, a ordem civil e a ordem política? Para se obter a maximização das funções de cada ordem estas não deveriam ser sempre mutuamente exclusivas e a ordem política entendida apenas como ordem de serviço público?

Em quarto lugar, não deveriam ser os grupos (coetus) as unidades mínimas de soberania? Não deveriam ter idêntico poder entre si, independentemente da sua origem ou dimensão - um grupo, um voto ${ }^{7}$ ? Não se valorizaria assim a acção ética ou solidária no interior de grupos sociais activos ou sociedade em acto (logo, acção não individualista ou egocêntrica) e afirmaria que o estado de sociedade é desejável em relação ao individualismo? Os grupos permitiriam compatibilizar ego com alter e resultariam do exercício da sociabilidade activa. Nesse contexto, não deveriam os partidos políticos ser considerados grupos como quaisquer outros, sem beneficiarem do monopólio da representação coetocrática?

Se a principal patologia do antigo regime, aos olhos da democracia, era a aristocracia, hoje, a principal patologia da democracia, aos olhos de uma eventual futura coetocracia, não será o sistema partidário?

Em quinto lugar, não deveria a ordem política ser imanente da ordem civil e resultar da representação de grupos (coetus) auto-organizados livremente e a funcionar em democracia directa, uma vez que está provado que a "democracia" se mostrou inversamente proporcional ao tempo e ao espaço? De facto, é só no seio dos grupos (dimensão temporal e espacial limitada) que parecem ocorrer condições de actualização da democracia directa (Graeber, 2013) e, portanto, não devemos esperar que residam nos grupos as melhores condições para a emergência de decisões "democráticas" ou seja, maior coesão e capital social de tipo positivo? Não deveria a democracia ser reservada aos grupos civis e a coetrocacia à organização do Estado? Não seria por isso desejável que só a partir de grupos sociais activos e com estatutos definidos e públicos, fossem eleitos os representantes grupais, de entre os quais se constituiria posterior e hierarquicamente a ordem política (polis civil ética ou nova polis)? 
Em sexto lugar, não deveria o sistema de representação interditar a auto-candidatura a funções de representação política, resultando a legitimidade coetrocrática de eleições dos representantes grupais por livre escolha e indicação de iniciativa individual dentro de cada grupo (democracia directa)? Não se evitaria assim que os representantes políticos se movessem por interesses pessoais ou partidários e se conseguiria que a ordem política fosse constituída por verdadeiros representantes coetocráticos, investidos de legitimidade pelos seus grupos que directamente representariam, e dos quais seriam porta-vozes?

Em sétimo lugar, não seria desejável que a participação política fosse feita exclusivamente através da participação em grupos os quais elegeriam o seu eleitor, participação essa não obrigatória, garantindo-se assim simultaneamente a liberdade de cada indivíduo participar na polis e a existência de uma polis verdadeiramente imanente de uma civitas solidária?

\section{Conclusão}

Depois desta reflexão em forma interrogativa gostaríamos de concluir com novas interrogações sintéticas acerca de como devolver o poder à civitas, sem aniquilar a polis e sem ter de fazer dela uma elite maquiavélica no correcto sentido (tirania), ou no sentido do senso comum (máfia). Assim:

1 - Não será que uma solução para a crise da democracia possa ser a reconstrução da polis através de um novo sistema de representação constituído como ordem ou estado independente, mas verdadeiramente imanente da civitas?

2- Não será que um novo sistema político que incorpore a valorização da acção social orientada contra o individualismo permitiria encontrar um equilíbrio mais justo entre liberdade e igualdade e promover uma sociedade mais inclusiva e coesa?

3 - Não será que a recuperação de uma dimensão mais societal (coetus) da soberania produziria simultaneamente uma polis mais justa e equilibrada e uma civitas com indivíduos mais livres e solidários onde se desenvolvesse um forte capital social positivo? 4 - Não será que uma polis nobilitada e constituída como ordem ou estado, protegido por lei própria ou estatuto privado, permitiria menores níveis de corrupção ao nível do Estado?

5 - Não será que uma polis hierarquizada por mérito próprio dos seus membros (escolhidos como eleitores, por democracia directa dentro de grupos) garantiria uma 
moralização ética e uma nobilitação da acção política transformada em serviço público apenas?

Poderíamos através da coetrocacia atingir finalmente o terceiro princípio iluminista, a fraternidade? Lançamos a pergunta. A história, talvez, nos dê a resposta.

\section{Notas}

${ }^{1}$ Referimo-nos à pressão do social sobre o político pela importância crescente de movimentos sociais, movimentos populacionais cruzando as fronteiras territoriais das dominações políticas, estabelecimento de redes de contactos, nomeadamente virtuais e desterritorializados que dão origem a capitais social supranacionais, mas também à supremacia da sociedade não política na sua expressão económica no mercado global.

${ }^{2}$ Capital que fecha as pessoas dentro de grupos e as isola da restante sociedade.

3 “À medida que aumentam as PPP, diminui a eficiência do serviço prestado. Ou seja, nos hospitais-empresa, os serviços são mais caros e o Estado gasta mais do que gasta se fizer o mesmo num hospital público. Mais 0,5\% na última década” (Varela, 2012: 95).

${ }^{4}$ Consulte-se: http://pmcruz.com/eco/

5 "Usamos dados que têm a ver com impostos que recaem sobre o trabalho e subtraímos a esse valor os gastos sociais do Estado. As conclusões a que chegámos é que, na esmagadora maioria dos casos, os trabalhadores pagam mais do que recebem do Estado, em diverso tipo de serviços...Depois admiram-se que a segurança social tem uma dívida...Outro número escandaloso são as PPP rodoviárias. Mesmo que as pessoas deste país não andem nas autoestradas, estão a pagar como se lá andassem, porque o Estado garantiu a algumas empresas uma renda fixa, independentemente de passarem lá carros ou não. Ou seja, é um capitalismo sem risco. Não é aquela ideia do capitalista empreendedor que corre riscos para ganhar lucro. É a ideia do capitalista que não vive sem a cobertura do Estado...Para nós cai por terra o mito da economia privada e empreendedora, sobretudo no que diz respeito às grandes empresas, porque as pequenas empresas não são nada favorecidas nestas questões e estamos a falar de grandes conglomerados económicos. As grandes empresas vivem à conta dos impostos do Estado. Ou seja, não sobrevivem nem têm lucros se não contabilizarmos a massa de valor que é transferida para estas empresas através de esquemas, que são muitos" (Varela, 2012: 59). 
${ }^{6}$ Aquela que estabelece a desigualdade com base na posição dos indivíduos no processo produtivo.

${ }^{7}$ Se o valor social dominante for a ética e a solidariedade, não poderemos dizer que um grupo tem mais importância ou valor por ser maior. Cada grupo é um "produtor" de sociabilidades, de solidariedade e, portanto de sociedade e coesão. Assim o mérito dos grupos é alimentarem a coesão social, independentemente da sua dimensão e da sua finalidade (excluindo-se naturalmente grupos com acções anti-sociais).

\section{Referências}

Becerra da Costa, J. (2012). Estudo preliminar. In W. Whitman, Visões democráticas (pp. 11-41). Guimarães: Opra Omnia.

Cuz, P. M. (2013, Dezembro 23). Um ecossistema político-empresarial Portugal 19752013: visualização interactiva dos membros de Governos de Portugal com empresas e grupos. Consultado em 18 de Maio de 2016. Disponível em: http://pmcruz.com/eco/

Fukuyama, F. (1992). O fim da história e o último homem. Lisboa: Gradiva.

Gaggi, M. e Narduzzi, E. (2008). Low cost o fim da classe média. Lisboa: Editorial Teorema.

Graber, D. (2013). Projecto Democracia. Lisboa: Editorial Presença.

Lei $n^{\circ}$ 64/2013, de 27 de Agosto. Diário da República: I série, no 164/XII/2 (2013.08.27). Consultado em 16 de Março de 2016. Disponível em: https://www.parlamento.pt

Maquiavel (2011). O Príncipe. Lisboa: Círculo de Leitores.

Nunes, A. S. (1977). Questões preliminares sobre as ciências sociais. Lisboa: Editorial Presença.

Paiva, A. (2007). António Damásio e a "nova Sociologia". Brotéria - Cristianismo e Cultura, 164 (2), 131-150.

Schnapper, D. (2002). La démocratie providentielle essai sur l'égalité contemporaine. Paris : Gallimard. 
Schnapper, D. (1994). La communauté des citoyens sur l'idée moderne de nation. Paris : Gallimard.

Tocqueville, A. (2002). Da democracia na América, Oeiras: Princípia.

Varela, R. (2012). Quem paga o Estado Social em Portugal? Onde nos leva esta crise económica? O estado de bem-estar europeu tem futuro? Dívida Pública: dívida de todos ou negócio de alguns? Lisboa: Bertrand Editora.

Warnier, J. P. (2000). A mundialização da cultura. Lisboa: Editorial Notícias.

Weber, M. (2000). A Política como Profissão. Lisboa: Edições Universitárias Lusófonas.

Weber, M. (1999). Economia e sociedade: Fundamentos da sociologia Compreensiva. São Paulo: Editora Universidade de Brasília. 